\title{
A Formula For Job Creation: Tax Law Changes For Small Businesses
}

Patricia T. Papachristou, (Email: ppapachr@cbu.edu), Christian Brothers University James O. Parker, (Email: jparker@cbu.edu), Christian Brothers University

\begin{abstract}
The Bush tax cuts in 2001 (Economic Growth and Taxpayer Relief Reconciliation Act, (EGTRRA) and in 2003 (Job Growth and Taxpayer Relief Reconciliation Act, JGTRRA) are touted as providing an aid to the economy's recovery and job creation. The data shows that George Bush's first administration had the most anemic job expansion in decades and actually saw negative net jobs created. We advocate four tax changes for small businesses that would postpone the timing of taxes and make it easier for small businesses to survive. As small businesses provide more than two-thirds of the net new jobs created each year, insuring their sustainability will go a long way to foster small business expansion and more job growth among suppliers. Currently a third of new small businesses fail within their first two years and the failure rate exceeds 60 percent by the end of the sixth year. These tax proposals for small businesses resemble "laser surgery" for the economy instead of the "chemotherapy" of tax cuts for the whole economy. These proposals focus where twothirds or more of new jobs are created each year and will help small businesses manage their cash flow more effectively and encourage their long term sustainability. It is time for Congress to enact measures that help provide small businesses with a source of capital rather than draining them of the vital cash that they need. Such measures would not require government handouts or loans but, rather, would for the most part, merely entail postponing the taxation of business profits so long as those profits remained in the business to help insure its survival and growth.
\end{abstract}

\section{WHAT THE FEDERAL GOVERNMENT SHOULD BE DOING}

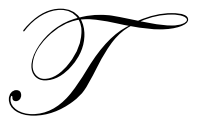

wo-thirds of George W. Bush's tax cuts went to the top one percent of the population. The average family received a few hundred dollars that were more likely to be spent on consumer electronics from Asia, instead of American manufactured goods. Thus these tax cuts did not have the predicted Keynesian stimulative effect in the United States. Consequently, despite the biggest tax cuts in history and a government deficit that was 3.5\% of GDP in 2004, there were no net jobs created in George W. Bush's first term in office. Even the Economic Report to the President, 2005 claimed employment would regain its pre-recession level only in the first quarter of 2005 (p.119). In Dec. 2005 the employment ratio was 66.0\%, still below the pre-recession peak of 67.3\% (Economic Report to the President, 2006, p.329).

Rather than cutting taxes and hoping that consumers use their increase in disposable income to buy American made goods and stimulate the U.S. economy, rather than buying Asian or European goods and stimulating those economies, it is time for Congress to break with tradition and enact some tax measures that directly benefit U.S. small businesses and thereby foster the job creation that will result from their increased numbers. The latest tax cut that George W. Bush signed into law on May 16, 2006 gives an estimated 80 percent of the tax savings to the top 10 percent of tax payers. Bruce Bartlett, a former Treasury economist justified the tax changes on the basis that "poor people don't create jobs, and rich people do." (Christian Science Monitor, May 22, 2006, p.15). Despite the tax law changes enacted by the Bush administration we have yet to see our employment ratio rise above its pre-recession level. The last four years of the Clinton administration had an employment ratio of 67.1 percent. The types of measures called for should prove highly cost effective since they often involve mere postponement of taxation rather than its elimination. The specific tax changes that we recommend for small businesses are 1) the right to choose the cash method of accounting, 2) the right to deduct expenditures which increase inventory, 3) more liberal provisions 
for expensing investments in capital goods, and 4) the right to accumulate a significant amount of retained earnings at either low rates of taxation or free of taxation. Before discussing each of these proposals in detail, it is helpful to describe the role small businesses play in the American economy.

\section{THE ROLE OF SMALL BUSINESSES IN THE AMERICAN ECONOMY}

The truth of the matter is that small businesses and their owners form a sort of informal "partnership" with a host of various parties. Lenders who choose to make loans to small businesses will prosper or suffer as their debtor prospers or suffers. Interest income from performing loans will enable lenders to make further loans to other businesses, whereas loan defaults will leave the lenders unable to make as many such loans and may even bring their own survival into question. Suppliers who provide goods to small businesses on credit are in a similar position as that of money lenders and even suppliers who do not extend credit will feel the sting of declining sales and profits when the small businesses they were supplying shut down. Likewise, landlords, suppliers of utilities and telephone services, insurance companies, transporters, equipment makers, workers and a host of others who sell their goods and services to small businesses will "share" in the success or failure of the small businesses with which they do business.

The federal government is unique among the informal "partners" of U.S. businesses. The government takes its share of business profits in the form of taxes. It not only collects those taxes directly on the profits of each business, either from the business itself, from its owners, or from both, but it also collects taxes from the wages that it pays its employees and from the earnings realized by the other informal "partners" of the business as a result of their transactions with one another. Yet, despite its huge potential to realize revenue from the commercial activity of small businesses, the federal government in the U.S. does little to directly foster their success. In fact, if the federal government were an actual partner in the small businesses that it taxes, it would be a poorly behaved one. The government insists on taking its share of profits, in the form of taxes, at the very first showing of a profit, and in cash, regardless of how serious a negative impact this may have on the business.

\section{TAX PROPOSAL ONE: THE RIGHT TO CHOOSE THE CASH METHOD OF ACCOUNTING}

Section 446-I(c) (2) of our current Internal Revenue Code (I.R.C.) provides that corporations that sell goods rather than services must adopt the accrual method of accounting. An exception for those engaged in the business of farming is provided for in I.R.C. $\S 448$ as is the requirement that even corporations that market nothing but services must switch to the accrual method of accounting when their gross sales reach $\$ 5,000,000$ per year, averaged over the previous 3-taxable-year period. There is a further exception for qualified personal service corporations that allows them to remain on the cash method of accounting even when gross sales exceed the $\$ 5,000,000$ limit and the company is a service company in which all of the shareholders are employed by the business and actively participate in its operation. Conversely, there is an exception which prohibits tax shelters from using the cash method of accounting even if they sell no goods. Entities other than C corporations which attribute more than $35 \%$ of their losses to parties who do not "...actively participate in the management of such enterprise," and who are not limited partners are considered to be tax shelters under the provisions of I.R.C. § 464(e)(2).

Still another provision allowing for the use of the cash method of accounting by businesses with average gross receipts over the last three years of less than $\$ 10,000,000$ came into effect by virtue of Revenue Procedure 200228 for years ending on or after December 31, 2000. This provision is somewhat complex and does not apply to businesses that come within certain codes of the North American Industry Classification System (NAICS). The ineligible industries are involved in mining, manufacturing, wholesale trade, retail trade or certain information industries. The NAICS codes are available on line at www.census.gov by selecting "subjects A to Z," then selecting "N" and finally selecting "NAICS (North America)." Obviously, the excluded industries are those that deal in goods rather than services, for the most part.

An exception at the other end of the spectrum is provided for in Revenue Procedure 2001-10 which permits even corporations that sell goods to use the cash method of accounting if their average annual gross receipts do not exceed $\$ 1,000,000$ for each of the prior tax years ending after December 16, 1998. The relatively small amount of 
gross receipts permitted for this exception effectively prevents it from having the impact on economic growth that it could.

The fact that a taxable entity must recognize accounts receivable as if they were actual receipts under the accrual method of accounting will not create problems as long as the total of its accounts payable equals or exceeds the total of its accounts receivable since the accounts payable will be treated as if they were actually paid when they are merely accrued under the accrual method of accounting. However, serious problems can develop when a company on the accrual method of accounting earns a profit and that profit takes the form of accounts receivable. The result is a tax liability without any cash with which to pay it. Out of desperation, the business owners in such a situation often raise cash by "selling" their accounts receivable, a practice known as "factoring." In order to entice someone to give them cash for their accounts receivable the business owners must be willing to transfer the accounts at less than their full value. The amount of such discount in the value of the accounts receivable is often 5\% to $10 \%$ and this represents the return which the party obtaining the accounts expects to make on the transaction. If any of the accounts prove to be uncollectible, since the transfers are usually with full recourse, the business must buy back the defaulting account.

Factoring may enable a business to meet its short-term cash needs but it is accomplished at a dear price. Although the 5\% to $10 \%$ discount may sound relatively modest, it must be remembered that the net profit generated by the factored accounts may not be much larger than the discount. For example, if a company were generating a net profit of $12 \%$ on its sales and were paying a $7 \%$ discount in order to factor its accounts, the business would be surrendering over half of its profits in order to obtain cash in what would probably be a mere 30 to 60 days sooner than it otherwise would. Furthermore, once a company starts to factor its accounts it is often very difficult for it to stop. This is due to the fact that once a company factors the receivables that it generates for a month, it will have no income for the month in which those receivables come due since they will be paid to someone else. Therefore, it will likely be necessary to factor subsequent months' receivables in order to obtain cash to replace the previously factored receivables. If the business experiences even one or two poor months, the company may lack the profits with which to even cover the cost of factoring. Even if the company can cover the cost of continued factoring, the reduced revenue from factoring smaller levels of receivables due to sales declines, and the erosion of past profits due to the cost of factoring may still doom the business to failure.

If small businesses were allowed the option of adopting the cash method of accounting, regardless of whether or not they sold goods, the problems associated with having to pay taxes on profits that take the form of accounts receivable would be eliminated. The justification for requiring the accrual method of accounting is to prevent businesses from distorting their profits by paying obligations in advance. However, businesses who were allowed to deduct such advance payments would merely be altering the timing of taxation rather than avoiding it since the deductions taken prematurely would not be available in subsequent years.

It has already been recognized that giving small businesses the option of adopting the cash method of accounting may prove beneficial to them as evidenced by the various exceptions for small taxpayers which permit corporations to use the cash method of accounting. If such a provision is beneficial to small businesses and can help insure their survival and the job creation that results, then the provision should be extended to all small businesses. Regulations can always be promulgated to prevent outright abuse of the provisions.

\section{TAX PROPOSAL TWO: DEDUCTION OF EXPENDITURES TO INCREASE INVENTORY}

One of the most common misconceptions held by the American public is that if they were to start a small business that they would only have to pay taxes on monies that were actually distributed to them from their company's profits. Therefore, they figure that the degree to which they can use profits to increase their inventories they will avoid taxation on those profits until such time as the inventory is sold. This is simply not true.

Under current U.S. tax law, any of a company's taxable profits that are used to purchase additional inventory by a $\mathrm{C}$ corporation, or organization taxed as if it were a $\mathrm{C}$ corporation, are taxed in the same manner as if those profits were either accumulated as retained earnings or paid out as dividends. The tax treatment of profits used by partnerships to acquire inventory may be even more troublesome to taxpayers. Partnerships themselves do not pay taxes as an entity. Rather, they file a return showing their profits, which includes a form " $\mathrm{K}-1$," a copy of which is 
sent to each owner, allocating those profits to the partners in accordance with their partnership agreement or, in the absence of an agreement as to the allocation of profits, on the basis of each partner's ownership interest. Each partner must then report his individual share of partnership income shown on his form K-1 on his personal tax return. If the partnership income were used to buy inventory for the partnership, rather than distributed to the partners, the income still must be reported by the partners on their individual returns and they will find themselves in the unenviable position of having taxable income without having received a distribution with which to pay the taxes on it. The same tax treatment applies to entities that are taxed as if they were partnerships. Foremost among them are qualified small corporations who make an election under the provisions of I.R.C. $§ 1362$ to be taxed under Subchapter S of the Internal Revenue Code and limited liability companies that elect to be taxed as partnerships under the provisions of Treasury Regulation $\S 301.7701-3$. Owners of these types of organizations who are not particularly active in their management may have no idea that the organization they have an investment in has generated profits which have been invested in inventory until they receive their form K-l after the close of the year.

Unlike the situation in which a company realizes its profits in the form of increased accounts receivable, when a company realizes profits in the form of an increase in inventory, it does not then have an asset that it can factor to raise needed cash. Unless the company is in a position to borrow money to distribute to the owners to use to pay their tax liability, owners who are confronted with a tax liability on earnings used by the company to buy inventory and are unable to obtain a personal loan to cover the taxes, may be forced to file their returns showing the liability that is due, but without paying it. The taxpayer will then be required to pay the delinquent tax liability, along with relatively high interest, on installments. Of course, earnings from which the installment payments will be made will also be subject to regular taxation. This combination of installment payments with interest and regular tax payments on earnings may not leave the taxpayer much to meet his living expenses. Almost certainly business owners put in this position will be unlikely to continue to use profits to fund increases in inventory which, in turn, will stifle growth that is dependent upon expansion of inventories.

Rather than discouraging small businesses from using profits to expand inventories and create growth that may be fostered by that expansion, we should be encouraging such a use of profits. This could be accomplished by a provision as simple as allowing small businesses to postpone taxation on profits to the extent that those profits were used to increase inventories. The key word in this proposal is "postpone." When companies sell the inventory that they previously acquired with untaxed profits they would be taxed on the previously deferred profits unless those receipts are further invested in still more inventory. Such a provision would allow small businesses to help finance their inventory needs with funds that would otherwise go to pay taxes, but companies who over-invest in inventory in an effort to avoid taxation would still ultimately be taxed as they liquidated their excess inventory. It does not seem likely that many businesses would be prone to abuse such a provision by continuously expanding excess inventory, since most owners would certainly prefer to have cash for other business uses or distribution, rather than acquiring inventory that they did not need. It is true that businesses could manipulate the incidence of taxable income to an extent by building inventories during highly profitable years and reducing inventories in years of little or no profit. However, rather than being an abuse of the tax law, this would seem to be sound business management made possible by a sensible tax law. To the extent that small businesses were able to survive lean times by liquidating surplus inventories acquired by tax deferred dollars earned in prior years, the country and the economy would be well served, as businesses that would have otherwise failed continue to provide jobs to workers who continue to be taxpayers rather than recipients of unemployment benefits.

\section{TAX PROPOSAL NUMBER THREE: EXPENSING RATHER THAN DEPRECIATING INVESTMENTS IN CAPITAL GOODS}

Just as many potential promoters of small businesses mistakenly believe that they can deduct their investments in inventory for tax purposes, they also believe that they can avoid taxation on profits by using their income to buy equipment rather than distributing the profits to the owners. Although there is some truth to this popular belief, it is not entirely true.

Section 162 of the Internal Revenue Code currently permits companies to fully deduct the cost of items in the year in which they were acquired if they are not expected to last for a year or more and are "ordinary and necessary" 
business expenses. Expenditures for capital assets, those that have a relatively long expected useful life, such as machinery and equipment, cannot be "expensed," the term used when an expenditure is fully deducted from taxable income in the year in which it was incurred. Rather, deductions for expenditures for capital goods must be taken in the form of depreciation over the assigned life expectancies of the goods under provisions in the Internal Revenue Code known as the Asset Cost Recovery System (ACRS). The assigned life expectancies are somewhat arbitrary in that some assets are likely to last well past their assigned lives whereas others cease to be useful prior to their life expectancies.

In most cases the owners of capital assets are allowed to choose between depreciating their assets in equal installments over their expected lives, straight-line depreciation, or taking double the straight-line percentage and applying it to the underdepreciated balance, the double declining balance method. To the extent that the funds used to acquire capital goods are borrowed, no tax liability will arise in connection with the funds since borrowed money is not considered to be taxable income. However, to the degree that profits are used to acquire capital goods, those making such investments will, once again, face the situation in which taxes will be due on their profits but the monies earned will not be available with which to pay those taxes. To the degree that depreciation may be taken on the capital goods purchased, the tax liability on profits used to make such a purchase will be offset. But this will only lessen the tax problem rather than eliminate it since there will be a substantial portion of the purchase price that cannot be offset by depreciation.

Section 179 of the Internal Revenue Code benefits small businesses by allowing them to expense up to $\$ 25,000$ per year of expenditures in 2003 and beyond that would otherwise have to be depreciated. To the degree that the cost of an asset is expensed it will not be eligible for depreciation. Once total annual expenditures for capital goods exceed $\$ 200,000$, the eligibility to expense part of the cost is phased out, thereby limiting this exception to small businesses.

Obviously, lawmakers see the wisdom of allowing small businesses to take tax deductions early for expenditures to acquire capital goods, as evidenced by the options to choose accelerated depreciation and to even expense up to $\$ 25,000$ of annual capital expenditures. Why is the option to expense the cost of capital goods arbitrarily set at $\$ 25,000$ ? If being allowed to expense their entire investment in capital goods would enable businesses to increase their expenditures for those goods and thereby increase their growth and/or survival rates, it would only make sense to allow them to do it. Such a change could readily be accomplished by simply modifying the existing provisions which allow for the limited expensing of capital expenditures and either eliminating the limit or dramatically raising it. If the goal were to limit such an option only to small businesses, this could be accomplished by leaving a cap in place beyond which expenditures for capital goods could not be expensed at all.

Unlike the provisions of the U.S. tax code concerning depreciation, which make it mandatory to take depreciation on capital assets beginning in the year in which they are placed in service and continuing each year over the assigned life of the asset, the option to expense capital goods should be entirely optional. The current provisions, which allow limited expensing of expenditures for capital goods, permit such expending only in the year of initial acquisition of the goods. If the law were changed to permit unlimited expensing of such purchases, it would be advantageous to permit businesses to expense their investments in capital assets at any time over the anticipated life of the asset. Under such a provision, businesses with too little income to benefit from such a tax deduction could save it for future years when they were more profitable. In fact, if unlimited expensing of investments in capital assets were permitted in a system that allowed businesses to expense as much or little of their expenditure each year over the life of the asset as they chose, such a system could replace our current provisions for depreciation altogether.

As with other suggested tax law changes herein, allowing businesses to expense their investments in capital goods at their discretion over the expected life of the assets would, to a large extent, merely alter the timing of the incidence of taxation rather than eliminating taxation altogether. Businesses that elected to fully expense capital investments in the year they were incurred would realize tax savings that may be needed to help cover the cost of those investments but, in doing so, they would incur higher taxes in future years than they would have had they elected to spread the deduction out over the life of the assets. Likewise, businesses that elected to save the write offs for capital investments for fixture years might do so at the cost of greater tax liability in the earlier years of the assets' 
expected lives. Admittedly, there are businesses that would wisely use their deductions for expenditures for capital goods to reduce their aggregate tax burdens. However, there are probably a lot more businesses that would take the write offs as quickly as possible in an effort to raise immediate cash, even if it meant larger tax payments in the long run. Even if this were not the case, to the degree to which businesses could use such a tax. provision to aid in their growth or survival, the federal government would still likely be a net beneficiary when the taxes collected on the salaries of workers who would otherwise be without employment are considered.

Simulative tax legislation in the past has often included provisions for tax credits for investments in capital goods. For example, in the mid-1970s, to the degree that businesses invested in tangible property with at least a 3year-life and which was an important element in the company's productive process, they were permitted to take an investment credit that was generally $10 \%$ of the amount of the expenditure, depending on the nature of the property obtained. Since tax credits may be used to offset tax liability on a dollar-for-dollar basis, rather than merely reducing taxable income, they have a much stronger favorable impact on businesses than do measures that increase the amount of depreciation that may be taken by a similar percentage. For example, if a proprietor in a $27 \%$ tax bracket were to invest $\$ 25,000$ in equipment for which he could take a $10 \%$ tax credit, he could reduce his tax liability by $\$ 2,500$ as a result of the credit. Whereas, if that same party were merely allowed to take an extra $10 \%$ depreciation in the year of acquisition, he would merely reduce the amount of income to which he must apply the $27 \%$ tax rate by $\$ 25500$ and his net tax reduction would be only $27 \%$ of $\$ 2,500$, or $\$ 675$.

In recent years, investment tax credits have largely been limited to special situations such as the credit for expenditures necessary to comply with the Americans with Disabilities Act that is available to small businesses provided for in IRC. $\S 44$. However, the rationale for the more general investment credits of past years is still valid today. Not only do general investment credits provide some capital to businesses with which to acquire the capital goods they need to survive and grow, but, to the degree that new investments are stimulated by the investment credit, companies that supply the capital goods also prosper and grow. Increased growth and prosperity by businesses result in increased employment which generates more income for the federal government to tax and offset the revenue lost due to the tax credits. Perhaps it is time to take another look at tax credits, at least for small businesses.

\section{TAX PROPOSAL NUMBER FOUR: THE RIGHT TO ACCUMULATE SIGNIFICANT RETAINED EARNINGS AT A LOW TAX RATE}

Consumers seeking financial advice from books, magazines, radio talk shows, television shows or personal consultants are almost universally advised to accumulate a cash reserve equivalent to several months of living expenses with which they can survive periods of illness or unemployment. Similar advice would be good for small businesses. However, we do little to encourage businesses to retain earnings with which to meet their needs during lean economic times. Corporations that do not elect to be taxed as partnerships, as provided for in Subchapter S of the Internal Revenue Code, and are, therefore, taxed under Subchapter $\mathrm{C}$ of the Internal Revenue Code and are known as "C corporations," are permitted to accumulate a certain amount of retained earnings. The amount of earnings which $\mathrm{C}$ corporations may retain cannot exceed the reasonable needs of the company or LRC. §531 will cause the excess to be subjected to an accumulated earnings tax equal to the highest marginal tax bracket for individuals. Fortunately, L.R.C. $\S 536$ allows most $\mathrm{C}$ corporations to accumulate earnings of $\$ 250,000$ without any question as to whether the amount is in excess of the corporation's reasonable needs.

Companies that can demonstrate a genuine need to retain earnings in excess of $\$ 250,000$, using the criteria set forth in the Internal Revenue Code, will be permitted to further accumulate the appropriate retained earnings without having to pay the accumulated earnings tax.

Although the retained earnings provisions offer some tax relief to $\mathrm{C}$ corporations, the relief is not complete. Even earnings that are retained by $\mathrm{C}$ corporations are still subjected to corporate taxation. The tax relief comes by not forcing the corporation to distribute its after-tax earnings to shareholders in the form of a dividend which would then be further taxed when they filed their tax returns. 
In practice, most small businesses that are $\mathrm{C}$ corporations avoid the double taxation that arises when corporate profits are distributed as dividends by simply paying sufficient tax deductible salaries and bonuses to owners, who are employed by the company, so that the corporation does not show a profit. Of course, the recipient of the salary and bonus must pay income taxes and social security on them. With individual income tax brackets in the U.S. reaching as high as $38.6 \%$ for 2003 , it is quite possible that the income tax liability, plus the combined employer's and employee's shares of Social Security, could exceed $40 \%$ of the portion of an owner/employee's salary that is taxed in the recipient's highest income tax brackets. Since the first $\$ 50,000$ of taxable corporate income is taxed at only $15 \%$ and no social security taxes are levied on corporate income, it may be appealing to owners of a C corporation to forego bonus payments sufficient to allow the corporation to realize a taxable income of $\$ 50,000$, pay the $15 \%$ corporate income tax, and retain the remaining $85 \%$ of the income as working capital or emergency funds, as long as the company's retained earnings do not exceed its reasonable needs. The alternative would be for the owners to take their bonuses, pay their taxes and then make an additional capital contribution to the corporation with the approximately $60 \%$ of their bonus remaining after taxes. Some may still choose the alternative rather than face the prospects of taking the capital out at a future date and having it taxed as a dividend.

It is time for Congress to develop retained earnings provisions that are clearly beneficial to small businesses and are available to all of them. Since there is no incidence of taxation at the entity level for proprietorships, partnerships, or entities choosing to be taxed as partnerships, such as $\mathbf{S}$ corporations, they do not even have the limited retained earnings provisions available to them that the $\mathrm{C}$ corporations currently have. If businesses and their owners could avoid taxation of corporate profits to a degree by allowing the businesses to retain earnings to finance expansion or to prepare them for the periods of economic stress that are inevitable for virtually every business, there is no question that businessmen would take advantage of that opportunity. Improved growth rates and higher survival rates for small businesses would be inevitable.

Measures designed to place maximum limits on the amount of retained earnings that a business could avoid taxation on would be necessary, as would other limitations designed to prevent abuse of the provisions. Of course, to the degree that businesses later distributed retained earnings that had not been previously taxed, the distributions would then be subjected to taxation.

With provisions in place to tax previously untaxed retained earnings when they are withdrawn from the company, measures allowing a relatively liberal amount of tax deferred retained earnings would appear to, once again, merely affect the timing of the taxation on those earnings rather than exempt them from taxation altogether. However, once a business uses its retained earnings to meet shortfalls in paying its bills, or funds an advertising campaign, develops a new product line, or otherwise embarks on some sort of expansion program, the funds will be consumed and unavailable for distribution. To a large extent, companies would likely use their retained earnings for programs designed to enhance their business reputations, a concept referred to as "goodwill." Such expenditures often lead to increased sales and higher profits which will generate tax revenues but the actual goodwill generally remains on the company's books and does not generate a direct source of funds for distribution until such time as the assets of the business are sold or the business is liquidated. Upon liquidation, it would not be unreasonable to require business owners whose businesses had benefited from tax deferred retained earnings that remain untaxed and who then received distributions from the liquidation, to recognize the distribution as taxable income until the previously deferred retained earnings were fully offset. Such tax treatment would seem appropriate even if the funds distributed could be traced to the liquidation of assets that had been acquired with capital contributions of the owners. In essence, the tax deferral on retained earnings should be viewed as if it were a conditional capital contribution to the business by the federal government which, upon liquidation, is to be given priority as to repayment.

Since successful businesses may well operate for decades or even centuries, it is entirely possible that the period of tax deferral on these companies' retained earnings will last for a very long time. As a result, the Treasury will suffer some decline in revenue due to allowing small businesses to defer taxes on retained earnings. However, this should not be cause for alarm since there are so many potentially beneficial developments that are likely to result from a healthier economic environment for small businesses. 


\section{CONCLUSION}

In a recent speech to the National Economists Club on February 14, 2005, Gregory Mankiw, Chairman of the President's Council of Economic Advisors, discussed tax reform and stated that tax code changes would continue to be made to 'make the tax code simpler, to make it more fair, and to further promote growth and job creation." There is little reason to believe that additional Keynesian tax changes would create more new jobs in the United States. Now is the time to amend the current laws so that they create a more favorable economic environment in which small businesses can survive and grow since America's small businesses account for over two-thirds of its net jobs created each year.

To the extent that the federal government levies taxes on the profits of small businesses, those funds will not be available to the companies to sustain them and to finance growth. When small businesses fully utilize their profits to support expansion, often without even realizing what the consequences of what they have done will be, they leave themselves and their owners with taxable income but with no cash with which to pay the taxes. In essence, our current tax laws punish small businesses that undertake aggressive growth programs rather than rewarding them.

It is time for Congress to enact measures that help provide small businesses with a source of capital rather than draining them of the vital cash that they need. Such measures would not require government handouts or loans but, rather, would for the most part, merely entail postponing the taxation of business profits so long as those profits remained in the business to help insure its survival and growth. These proposed tax measures should be very cost effective. They largely involve mere postponement rather than elimination of taxation. Even to the degree that the measures result in specific reductions in federal tax collections, their net effect should be quite positive overall. In light of the ability of small businesses to create so many new jobs in the U.S., even a modest improvement in the small business survival rates should translate into millions of new jobs and billions of dollars of tax receipts from the workers' wages.

\section{REFERENCES}

1. Bureau of Labor Statistics.

2. Economic Agenda, Remarks at Macroeconomic Advisers Washington Policy Conference by Dr. N. Gregory Mankiw, September 9, 2004 (http://www.whitehouse.gov/cea/economic-agenda.html).

3. Economic Report to the President,2004, 2005.

4. $\quad$ Francis, David R. Simplified Tax Code: A Tough Sell, Christian Science Monitor, October 24, 2005, p.16.

5. _ Why the Rich Get the Most Tax Goodies, Christian Science Monitor, May 22, 2006, p.15.

6. Groshen, Erica L. And Simon Potter. Has Structural Change Contributed to a Jobless Recovery, Current

Issues in Economics and Finance, Federal Reserve Bank of New York, August 2003 (Vol.9 No.8), http://www.newyorkfed.org/rmaghome/curr-iss(http://ssrn.com/abstract=683258.

7. Helyar, John. 50 and Fired, Fortune, May 16, 2005 (Vol.151No.10), pp78-80.

8. Hilsenrath, Jon E. and Sholnn Freeman. So Far, Economic Recovery Tilts to Highest-Income Americans, Wall Street Journal, July 20, 2004.

9. Internal Revenue Code.

10. Ip, Greg. Job Data Might Be a Salve for Bush, Wall Street Journal, August 8, 2005, p. A2.

11. Parker, James O. Tax Power for the Self-Employed: Straightforward Advice from an Expert, Naborville, Illinois: Sphinx Publishing Co., 2005.

12. _ The Real Estate Investor, Naborville, Illinois: Sphinx Publishing Co., 2006.

13. _. Tax Smarts for Small Business, Naborville, Illinois: Sphinx Publishing Co., 2004.

14. Schreft, Stacy L. and Aarti Singh. A Closer Look at Jobless Recoveries, Federal Reserve Bank of Kansas City, Economic Review, 88, No.2, pp45-73.

15. Schweitzer, Mark. Another Jobless Recovery? Federal Reserve Bank of Cleveland, Economic Commentary, March 1,2003. 